\title{
Property, Bodies and Wittgenstien
}

\author{
H. McLachlan*
}

School of Law and Social Sciences, Glasgow Caledonian University, Cowcaddens Road, Glasgow G4 OBA, UK

\begin{abstract}
It is Quigley's view that we should regard our own human bodies as our property. Wittgenstein's famous comments about games and family resemblances are cited in support of this contention. She thinks that classification of bodies as property is significant and that it will help us to answer the ethical and political questions about how we should treat and be permitted to treat body parts, tissues and such like.

This paper seeks to show that, although Wittgenstein's comments about games and family resemblances might help us to think more clearly about the philosophical problem of universals, they do not lead one to imagine that bodies are property. The comments, like the concept of property itself, do not have the normative force that Quigley claims for them and it. The question that we need to address is not whether or not our bodies are property but: what rights and duties do we have pertaining to our bodies and to our selves? Notwithstanding how we might subjectively react to the claim that bodies are property, nothing of crucial importance depends on its truth or falsity.
\end{abstract}

Key Words: Property, self-ownership, Wittgenstein, Honoré, nominalism, essentialism.

\section{INTRODUCTION}

Quigley argues that, in accordance with the theory of classification associated with Wittgenstein, we should consider that our own human bodies are our property [1,2]. She thinks that classification of bodies as property is significant and that it will be illuminating when we try to answer the ethical and political questions about how we should treat and be permitted to treat body parts, tissues and such like. Thus she writes: 'By including the body in the list of things which we now call property, we place it within a normative framework which can help to identify what issues really divide us when considering dilemmas about the use and control of our bodies and their parts' [3]. I do not think that our bodies are property. More importantly, I shall show that it is not of great significance whether or not our bodies are our property.

\section{WITTGENSTEIN, FAMILY RESEMBLANCES AND THE THEORY OF CLASSIFICATION}

Quigley bases her argument on the work of Honore [4]. She notes that Honoré cites eleven features of property or 'incidents of ownership'. She writes:

'According to Honoré, for full ownership in a thing to be recognised, an individual must hold most (but not necessarily all) of these elements regarding that thing.

This analysis incorporates the Wittgensteinian concept of family resemblance. Wittgenstein uses the example of games and shows us that there is no single characteristic or group of characteristics that all "games" have in common. There is, however, "a complicated network of similarities

*Address correspondence to this author at the School of Law and Social Sciences, Glasgow Caledonian University, Cowcaddens Road, Glasgow G4 0BA, UK; E-mail: H.McLachlan@gcal.ac.uk overlapping and criss-crossing: sometimes overall similarities". In the context of Honore's incidents, this addresses a major problem that is often associated with theories of property and ownership-namely, that not all things generally considered to be property share all the same characteristics or sets of characteristics. Honoré's approach is open and flexible, because while each of the eleven incidents of ownership may not be applicable to things we consider to be property, each item within the "group" of property will share similarities and relations with other items in the group' [5].

It is far from obvious what point he is trying to make when Wittgenstein suggests that games form a family, that there are family resemblances between them and that they share no feature in common. Wittgenstein claimed to hold no philosophical theories and it was his long-term view that, when properly conducted, philosophy does not result in the production of philosophical theories but in the eradication of the sorts of linguistic confusions that are, according to him, the tormenting causes of philosophical puzzlement. Hence, one cannot be sure that Wittgenstein would approve when he is cited as the supporter or originator of a particular philosophical theory. Nonetheless, one interpretation of Wittgenstein's remarks is that they are addressed to the philosophical problem of universals and offer a different solution from the traditional ones. The problem of universals is the question of what it is to be a member of the class of Xs, where X stands for a general term like, say, cat, dog, table, chair or game. The traditional answers are nominalism and essentialism. According to nominalism, Xs are Xs by virtue of being called Xs. On the other hand, according to essentialism, there is a defining characteristic of Xness that is common and peculiar to all Xs. Nominalism seems to have an initial appeal. After all, what unites members of the category of, say, 'Hughs' is that other people call them 'Hugh'. Membership of the category is open to all people, 
animals and things who and that happen to have that name. Yet, consider, say, the class of bachelors. Bachelors are not bachelors because they are called bachelors. Some bachelors are not called bachelors. Some people who are called bachelors and who purport to be bachelors are not bachelors. To misclassify a married man as a bachelor is a different sort of mistake from thinking or saying that someone who is actually called, for instance, 'John' is called 'Hugh'. Bachelors are, by traditional definition, unmarried adult male human beings. The combination of such features might be said to be an essence of bachelorhood which is common and peculiar to all bachelors. Wittgenstein's point has been interpreted, most notably by Bambrough, to be that some class terms fit neither the model of nominalism nor essentialism [6]. Games are not games merely because they are called such. Games are games by virtue of the features they possess. The features by virtue of which any particular game is a game, are not necessarily common - far less common and peculiar - to all games, in this interpretation.

Consider an artificial example for the sake of the illustration. We could give the name of 'elgies' to the members of the class of people who are eligible to be considered for selection for the Scottish international football team. My understanding of the current rules is that in order to be an elgy, one needs to have been either: a) born in Scotland of whatever parentage or: b) born outwith Scotland of at least one parent or grandparent who was born in Scotland. One is not an elgy by virtue of being called an elgy. Elgy is not a nominalist concept. It is not an essentialist concept. There is no feature by virtue of which elgies are elgies that is necessarily common to all elgies. It could well be that not all elgies were born in Scotland, not all elgies have a Scottish parent and not all elgies have a Scottish grandparent. Yet it is by virtue of the possession of one or more of these features that elgies are elgies. Elgy is what I would call a family membership concept. I specifically say family membership rather than, as Wittgenstein, Bambrough and Quigley do, family resemblances since, whether or not members of particular families happen to resemble one another more than they resemble non-family members, it is not by virtue of such contingencies that they are members of particular families. Family members are not members of a particular family because they resemble one another. Rather, because they are members of the same family, some of them resemble each other. Family membership is, nonetheless, a good analogy in this context because the feature or features by virtue of which a particular family member is a member of a particular family - birth, marriage, cohabitation, adoption, appellation and so forth - might be different in different instances $[7,8]$.

Not all concepts and class terms are family membership ones. Wittgenstein gives no reason for supposing that they are. I would suggest that class terms form a family like games and that the features by virtue of which particular class terms are class terms can vary from case to case. Some class terms are nominalist, some are essentialist, some are family-membership ones. There might be various other sorts of class terms. Some Xs are Xs not by virtue of the features they have but by virtue of what they do. Think, for instance, of engines. Engines do not resemble other engines except, perhaps, with regard to the tasks they were designed to perform.

\section{BODIES, MINDS, PERSONS AND PROPERTY}

It is possible that, as Quigley suggests, property is what I have called a family membership concept. However, she does not prove that it is. Similarly, it might be the case that our bodies are, in accord with such a concept, property but it remains an open question whether or not they actually are property. Quigley does not settle the matter.

In my view, property is a type of essentialist concept. There is, I suggest, a feature that is necessarily common to all actual and possible instances of property - the clusters of legal rights and duties that constitute the ownership of particular items of property can be transferred in characteristic ways at the behest of the owner. For instance, one can sell or give away a house which one owns and the cluster of rights and duties that pertain to it consequently become those of the buyer or the beneficiary. However, if, say, one is a parent, although one might hand over one's children to another party in return for money or offer them as gifts, the party does not thereby become the parent of or the owner of the children. Parenthood and children are not property unlike, say, the services of a baby sitter.

I am uneasy about the suggestion that our bodies as such could be regarded as property. The unease stems from conceptual rather than moral considerations. I doubt that we could own our selves as such or our bodies as such since I am not sure that it makes sense to talk of the transfer of such ownership. Our bodies, when we are dead, might be the property of our estates and become the property of other people. However, when we are alive, we have a particular relationship with our own bodies which is non-transferable. For instance, we cannot transfer to another the right to experience and control our own bodies in the way that we do ourselves. There are particular rights and duties pertaining to our bodies and our selves that we can transfer such as, say, the rights to the royalties from our writing. Similarly, for instance, photographs of my body and their copyrights might be property. Expressions of my thoughts, feelings and opinions and the rights to be associated with them as in the case of commercial endorsements can be property. However, I would suggest that we cannot own our own selves or our bodies since we cannot transfer our selves as such to another or transfer our particular relationship to our own particular bodies to another. We might talk loosely, say, of selling one's self into slavery. However, I suspect that the property pertaining to slavery is not the personhood or the living bodies as such of the slaves but particular attributes, services and features of them, especially the product of their labour.

People have bodies, minds, and brains but people are not bodies, minds or brains. They have moral and legal rights and duties concerning their bodies but they also have other rights and duties - both property and non-property rights concerning their selves. Dead people still have moral rights even although they have no bodies. Even if they have neither rights nor bodies, we can still have duties concerning them concerning them as persons rather than concerning their bodies. For instance, I have a moral right not to be slandered which is a right that I will still have long after my body has 
ceased to exist. It is not a property right. It is, for instance, not transferable.

\section{POSSESSION AND OWNERSHIP}

Ownership is different from possession. One can own property that one has never seen, touched or been in contact with. Honest people as well as thieves can have in their possession, on their person and even in their bodies, things that they do not own. For instance, my wife and I jointly own a particular flat. That means that we share a relationship to a bundle of rights and duties pertaining to it that can be transferred, under particular circumstances, to another person. However, if we had in our possession a baby, a phial of heroin or a bottle of extremely strong prescribed sleeping pills, we would not thereby necessarily own the baby, the heroin or the sleeping pills. If we passed the baby, the heroin or the pills to another person, a particular bundle of rights and duties would not simultaneously be transferred - whether or not money also changed hands - as would happen if, say, we sold or gave away our flat. Babies cannot be bought or sold despite what headlines in newspapers sometimes seem to say.

Notice too that if such things as, say, babies or drugs happened to be in one's possession, no matter how they came to be there, one would have duties concerning their disposal. For instance, suppose that on a walk in the country, one picked up a bundle and discovered it to contain a baby. One would have unexpected and unwanted moral and legal duties concerning the baby. Suppose that on what was one's property, cannabis was found to be growing. Since one cannot legally transfer ownership of the cannabis to another person under our particular legal system, I would say that one does not own the cannabis even if one owns the property on which it grows. However, the question of ownership is not pivotal. One would not be free to dispose of the cannabis as one willed whether or not one owned it. On the contrary, if it was one's property, it would be one's responsibility and one's problem. The owner of the cannabis would be the target of unwelcome and irksome questions and attention. Even if one did not own the cannabis but merely possessed it, one would still be the target of unwelcome and irksome questions and attention and, relative to the cannabis, be the bearer of few if any rights.

\section{PROPERTY, BODIES, RIGHTS AND DUTIES}

Suppose that someone asserted and another denied that a woman owns her own body and owns her foetus. Both people could still agree about the ethics of abortion and agree about what would be appropriate legislation with regard to it. For instance, both might say that abortion is generally morally wrong and should be illegal. Yet again, both might, say, for instance, that it should be legally permissible on request whether or not in general or in a particular instance it is immoral. Other positions can be adopted, none of them determined by the consideration of whether or not a foetus or a woman's body is property [9]. To say that we own something is not to say that we are morally entitled to do with it what we will. Similarly, it is not to say that we are or that we should be legally entitled to do with it what we will. If we own our houses, it does not follow that we can treat them in any way that we like.
Morally and legally, there are constraints on what we may do with our property. If, say, we try to knock our houses down or even, in some circumstances, paint them a particular colour, we might well be in breach of the law. If we own something, we often have thereby particular moral and legal duties that we would not otherwise have. Property entails burdens and restraint no less than it does privileges and entitlement. If we own something, we have rights regarding what we own that other people do not have but we similarly carry duties that others do not have with regard to what we own. For instance, we are responsible for the taxes that are levied on our properties. If our properties are a hazard to other people, we have particular duties to repair and amend them that other people do not have with regard to our properties. If a particular foetus is a particular woman's foetus whether or not the foetus and her own body are her property she is liable to be the bearer of particular moral duties towards and concerning the foetus. It might not be fair that she has these particular moral duties but whether we have particular moral rights and duties and whether it is fair that we have them are different questions. We have, for instance, moral duties to try to keep our own bodies clean and free of infection whether or not it is fair that we have the particular duties, infections or bodies.

To say that something is property might be to say that some one (or some agency) owns it and has particular duties and rights concerning it but not what the (moral and legal) rights and duties are other than that they might be transferred if particular conditions are met but not abandoned wantonly. We all know the figure of speech concerning white elephants. Behind it lies the literal truth than to be become the owner of a white elephant in a particular social context was to face ruin because of the cost of its upkeep. Sometimes, the rights of property ownership are slight and unavailing while the duties are burdensome and highly restrictive.

To declare that something or other, a living body, for instance, is property is to say little or nothing about how, morally or legally, it can or should be treated. For instance, some animals are the property of particular people while others are not. It does not follow that the latter are better treated or that the former may be treated by their owners with impunity. As I have argued elsewhere:

'One is not necessarily permitted to treat a cat which one owns in the same ways that one might treat an ' $\mathrm{X}$ ' which one owns. It depends what ' $\mathrm{X}$ ' stands for. Different instances of property relationships can involve different clusters of rights and duties. To say that one owns an ' $\mathrm{X}$ ' - say, an embryo is to leave pretty much open the question of the nature and content of the cluster of rights and duties involved. One might own, say, a lump of coal and a cat. Is one permitted, say, to set fire to such property of one's own? It depends. If the cat is dead, one might, if it is safe to do so, set it on fire. One might not set the coal on fire, whether it is safe to do so or not, if one lives in Britain in certain specified areas' [10].

\section{CONCLUSION}

It is possible but not certain that we could and should think of our bodies as property and consider ourselves to be 
the owners of our own ones. However, it does not matter. Nothing of significance hangs on the issue. With regard to the ethical and legal questions about what we should do and be allowed to do with our own bodies and what pertains to them, nothing follows from the claim that bodies are or are not property. Sometimes we own particular things but have no legal or moral right to do certain things to and with them. Sometimes we have such legal and moral rights even although we do not own the things in question.

Ownership and control are not the same things. Rights and duties of ownership can be different from rights and duties of control. For instance, parents have particular rights concerning the disposal and control of their children which the rest of us do not have concerning these particular children. However, the parents do not own these rights. Neither the rights nor the children are property. Neither the rights nor the children can be sold or given away as gifts. Similarly, although we have particular rights and duties of control concerning our own bodies, it does not follow that our bodies are our property. Not all rights and duties are property rights and duties. The question that we need to address is not whether or not our bodies are property but: what rights and duties do we have pertaining to our bodies and to our selves? Such rights and duties include moral ones and legal ones. They include property rights and duties and non-property rights and duties.

\section{REFERENCES}

[1] Quigley M. Property and the body: Applying Honoré. J Med Ethics 2007; 33: 631-4.

[2] Wittgenstein L. Philosophical investigations. Anscombe GEM, tr. Oxford: Basil Blackwell 1968; 32.

[3] Quigley M. Property and the body: Applying Honoré. J Med Ethics 2007; 33: 631 .

[4] Honoré AM. Ownership. Making law bind: essays legal and philosophical. Oxford: Clarendon Press 1987; 161-92.

[5] Quigley M. Property and the body: Applying Honoré. J Med Ethics 2007; 33: 632 .

[6] Bambrough R. Universals and Family Resemblances. Proc Aristotel Soc 1960; 61: 207-22.

[7] McLachlan HV. Wittgenstein, family resemblances and the theory of classification. Int J Sociol Soc Policy 1981; 1: 1-16.

[8] McLachlan HV. Buchanan, Locke and Wittgenstein on Classification. J Info Sci 1981; 3: 191-200.

[9] McLachlan HV. Bodies, rights and abortion. J Med Ethics 1997; 23: 176-180. Reprinted in McLachlan HV, Swales JK. From the Womb to the Tomb: Issues in Medical Ethics. Glasgow Humming Earth 2007; 12-20.

[10] McLachlan HV. Persons and their bodies: how we should think about human embryos. Health Care Analysis 2002; 10: 163. Reprinted in McLachlan HV, Swales JK. From the Womb to the Tomb: Issues in Medical Ethics. Glasgow Humming Earth 2007: $37-47$. 